\title{
THE EFFECT OF QUARRYING ON SOIL AND VEGETATION IN AKAMKPA LOCAL GOVERNMET AREA OF CROSS RIVER STATE, NIGERIA
}

\author{
E. C. NZEGBULE and F. EKPO
}

(Received 12 January, 2007; Revision Accepted 27 March, 2007)

\section{ABSTRACT}

The impact of tailing waste from quarry operations on the soil and vegetation in Akamkpa Local Government Area, Cross River State were investigated. The selected sampling areas $(0 \mathrm{~km}, 0.75 \mathrm{~km}$ arid $2 \mathrm{~km}$ or control $)$ were delineated based on the intensity of exposure to tailings and distance from the quarry Samples of the extracted material (chippings) was analyzed to ascertain the chemical composition. Samples of the soil $(0-5 \mathrm{~cm})$, fodder species Alchornea cordifolia and Aspilia africana. edible fruit Carica papaja and Mangifera indica as well as root and tuber species Manifiot esculenta and Colocasia esculenta were collected separately from each of the sampling area and analyzed for chemical characteristics. From the rock material, the concentrations of $\mathrm{Cu}, \mathrm{Pb}, \mathrm{Zn}, \mathrm{Fe}, \mathrm{Cd}, \mathrm{Ni}, \mathrm{Cr}$ and $\mathrm{Mn}$ in quarried materials (Chippings) were 9.28, 1.88, 10.64, 349.50, 2.06, 3.22, 1.12, and $2.44(\mathrm{mg} / \mathrm{kg})$ respectively. Quarry activities in Akamkpa affe ted the levels of $\mathrm{Pb}, \mathrm{Cu}, \mathrm{Zn}, \mathrm{Fe}, \mathrm{Mn}, \mathrm{Ni}$ and $\mathrm{Cd}$ in the soil as these element had significantly higher concentrations in the soils collected from the immediate vicinity of the quarry $(0 \mathrm{~km})$. Also the concentrations of the metals in the plants leaves within the quarrying site were significantly higher $(P<0.01)$ than that of the control $(2 \mathrm{~km})$. The concentrations of $\mathrm{Zn}, \mathrm{Cu}$ and $\mathrm{Ni}$ in leaves of Mangifera indica collected from the farthest sampling position from the quarry were lower by $81 \%, 63.04 \%$ and $51.93 \%$ respectively than that collected from immediate vicinity of the quarry sile. Quarry operation is causing increasing building of trace metals in the soils and vegetation in Akamkpa Local Government Area of Cross river State. Thus, the operations of the quarry industry need to be regulated to reduce the health risk the practice pnses to the local populace.

KEYWORDS: Quarry, Soil and vegetation

\section{INTRODUCTION}

Quarrying as a land use method is concerned with the extraction of non-fuel minerals from rocks (Okere $\theta t$ al 2001). Gravels for building houses and other civil construction are obtained from quarrying of rocks of the earths crust. There is now a great demand for rocks especially limestone as an essential constituent of many building and construction processes. A variety of products from mining and crushed rocks form primary raw materials in many industrial applications (Ellen, 2000). Crushed rocks are used as aggregate in high ways or concretes construction, in bituminous mixture and rail road ballast (Wills, 1995). However, several wastes are generated during the processes of extraction and crushing of rocks. Environmental disturbance and contamination as a result of mining and mineral processing activities constitute the major threats to public health and environmental quality (Adepoju, 2002).

The severity of the environmental problem depends on the characteristics of the mineral being extracted, the method of mining, waste materials generated and site characteristics. The effects of such problems are manifest in the air, land, plants, and water around with mining activity Tailing, a finishing ground particle of rock, are the most environmentally important component of the quarrying waste released into the environment. Tailing generated from mining operations and weathering of rocks is arnong the major sources of trace metals introduced into the environment. The pollution of soils and water with trace metals through atmospheric deposition is well known (Kakulu 2003, Nriagu 1990). Trace metals such as lead, Zinc, Cadmium, Copper Manganese and iron from mining activities can also occur as natural biochemical cycles (Mattigod et al, 1983, Brown, 1979) Although some trace metals are essential in plants nutrition plants growing in an environment with excessive accumulatici of trace metals suffer toxicity effect and pose serious risk to human health when such plant based foodstuffs are consumed (Vausta et al, 1996, Alloway, 1990). Unfortunately extensive research aimed at understanding the effect of these heavy metals and their cossible impacts on the environmert in Akamkpa Local Government Area have not been done; also the important regulatory policies to minimize their environmental effects are not yet formulated.

\section{MATERIALS AND METHODS}

\section{THE STUDY AREA}

The study area was at Akamkpa Local Government Area of Cross River State. Nigeria. The area lies between Latitude $6^{\circ} 50 \mathrm{~N}$ and $07^{\circ} 30 \mathrm{~S}$. The maximum annual mean daily temperature of the area is between $29^{\circ} \mathrm{C}$ and $34^{\circ} \mathrm{C}$ Akamkpa is characterized by the high rainforest vegetation. The two major seasons that prevail in the area are dry season (October-February) and rainy season with birnodal pattern (March-September). Short dry and windy periods of harmattan usually occur in the dry season. The mean annual rainfall is $2050 \mathrm{~mm}$. The soil in this area is clayey loam. Akamkpa has a population of about 95,000 people (NPC, 1991); and therr main occupation is farming. The farmlands are owned by individuals according to the traditional tenure sysiem and the major crops grown include cassava, maize. yam, okra and cocoyain

Quarrying activities started in 1982 in Obot Netim Village in Akamkpa Local Government Area of Cross River State. Presently the companies that are carrying out quarrying in the area are Crush Rock company, PRCDECO (Property Development company) and HITECH company.

\section{METHOD OF STUDY}

During the dry season and prior to sample collections, 3 steel coated pans were kept for 48 hours at the 3 different distances in order to ascertain the amount of dust produced during the quarrying process that could settle in the pans to delineate the positions where the samples were to be collected,. The pans were kept at $0 \mathrm{~km}, 0.75 \mathrm{~km}$ and $2 \mathrm{~km}$ away from the quarry site. This was done to determine the extent of spread of dust arising from the quarry operation and to establisin the point of control. The ccintents of the pans were checked after the 48 hours and point without settlement of dust particles was used as the control.

Six different plant species of economic value were

E. C. Nzegbule, Dept. of Forestry and Environmental Mgt, Michael Okpara Univ. of Agric. Umudike. PMB 7267 Umuahia. Abia State. Nigeria F. Ekpo, Akwa Ibom State College of Agriculture Obio Akpa, PMB 1001 Abak. Akwa Ibom State, Nigeria. 
identified to be occurring commonly in the 3 samplirg positions and were therefore selected as screening materials for he level of heavy metals. Leaf samples were collected from the 6 plant species (Table 1 ) in the 3 sampling locations using secautuer. The leaf samples were oven dried at $60^{\circ} \mathrm{C}$ to a constant weight, milled, sieved and digested

At each of the three sampling positions $10 \mathrm{~km}, 0.75$ $\mathrm{km}$, and $2 \mathrm{~km}$ ), a $50 \mathrm{~g}$ soil samples were collected randomly from a depih of $0-5 \mathrm{~cm}$ using soil auger. The soil samples were collected on 4 replicate points at each sampling location. The soil samples were air dried for 4 days, screened, sieved and digested. The different types of samples were digested and extracted using $0.1 \%$ perchloric acid. The extracts were analyzed for $\mathrm{Mn}, \mathrm{Cu} ; \mathrm{Fe}, \mathrm{Pb}, \mathrm{Ni}, \mathrm{Cr}, \mathrm{Zn}$ and $\mathrm{Cd}$ using the Atomic Absorption Spectrophotometer (Unicam 919 model) at central research Laboratory, University of Uyo, Nigeria Analysis of the crushed stones (Chippings) was done to support any inference that could be drawn on the accumulation of heavy metals in the area. Data collected were analyzed using the Analysis of variance (ANDVA) procedure (Steel and Torrie, 1980).

The least significant Differerice (LSD) was used to compare means along iows

\begin{tabular}{|c|c|c|}
\hline Plant Species & Class of Species & Economic importance \\
\hline $\begin{array}{l}\text { Manihot esculenta } \\
\text { (cassava) }\end{array}$ & Arable Crop & $\begin{array}{l}\text { - tubers used for making garri. } \\
\text { foo-foo. starch tapioca }\end{array}$ \\
\hline $\begin{array}{l}\text { Abeimochus esculentus } \\
\text { (okra) }\end{array}$ & Arable Crop & - fruit used as soup condiment \\
\hline Conlonacia osculenta & Arable Crop & - corm used as food \\
\hline $\begin{array}{l}\text { Carica papaya } \\
\text { (paw paw) }\end{array}$ & Cash crop & $\begin{array}{l}\text { - fruits used as food, } \\
\text { leaves as medicine, etc }\end{array}$ \\
\hline $\begin{array}{l}\text { Psidium guajava } \\
\text { (guava) }\end{array}$ & Cash crop & $\begin{array}{l}\text { fruits used as fcod. } \\
\text { leaves as medicine, etc }\end{array}$ \\
\hline $\begin{array}{l}\text { Mangifera indica } \\
\text { (mango) }\end{array}$ & Cash crop & $\begin{array}{l}\text { - fruits used as food. } \\
\text { leaves as medicine, etc }\end{array}$ \\
\hline Alchornea cordifolia & Fodder crop & - Feedstuff far livestock \\
\hline Centrosema pubscens & Fodder crop & Feedstuff for livestock \\
\hline Pennisetum purperum & Fodder crop & - Feedstuff for tivestock \\
\hline Pteridium acquilinum & Fodder crop & - Feedstuff for livestock \\
\hline
\end{tabular}

\section{RESULTS AND DISCUSSION}

The rock substance on subjection to analyses contairied various concentrations of different trace metals. The mean concentration of $\mathrm{Cu}, \mathrm{Pb}, \mathrm{Zn}, \mathrm{Fe}, \mathrm{Cd}, \mathrm{Ni}, \mathrm{Cr}$ and $\mathrm{Mn}$ in quarried materials (Chippings) were 9.28, 1.88, 10.64, 349.50 $2.06,3.22,1.12$, and $2.44(\mathrm{mg} / \mathrm{kg})$ respectively. The concentration of $\mathrm{Fe}$ in the quarried materials was highest compared to other metals, while $\mathrm{Cr}$ had the least concentration $(0.01 \mathrm{mg} / \mathrm{kg})$ in the same rock material. A similar study has shown that heavy metais can also occur as natural cycling from rocks but their various concentration depend on the type of parent material, age and formation (Mattigod et al 1983). The concentrations of $\mathrm{Fe}, \mathrm{Cu}, \mathrm{Zn}, \mathrm{Cd}, \mathrm{Cr}, \mathrm{Ni}, \mathrm{Pb}$ and $\mathrm{Mn}$ in the soils of the 3 sampling positions are shown in Table 2 . The highest concentrations of almost all the heavy metals determined were recorded from the sampling position in the immediate vicinity of the quarry $(0 \mathrm{~km})$ except in the case of $\mathrm{Cu}$. The concentrations of these heavy metals declined as distance from the quarry increases Apart from the levels of $\mathrm{Cu}$ and $\mathrm{Cr}$, other heavy metals had significantly higher level of their concentration in the immediate quarry vicinity than that occurring at the $0.75 \mathrm{~km}$ and $2 \mathrm{~km}$ sampling locations. The higher concentrations of heavy metals recorded in sampling position within the vicinity of the quarry could be a contribution from the tailing waste generated from the quarry which in itself contained high level of these metals. The soils from the other 2 locations farther away from the quarry had reduced heavy metal contents because the dispersal of the tailing wastes diminished in the area with increasing distance

Table 2: The mean concentrations ( $\mathrm{mg} / \mathrm{kg}$ ) of some heavy metals in the crusned rock (chippings)

\begin{tabular}{|ll|}
\hline Elements & Mean Concentration $(\mathrm{mg} / \mathrm{kg})$ \\
\hline Copper & $9.28 \pm 0.25$ \\
Lead & $1.88 \pm 0.18$ \\
Zinc & $10.34 \pm 1.27$ \\
Iron & $349.50 \pm 2.34$ \\
Cadmium & $2.02 \pm 0.05$ \\
Nickel & $3.22 \pm 1.55$ \\
Chromium & $1.12 \pm 0.02$ \\
Manganese & $2.44 \pm 0.01$ \\
\hline
\end{tabular}

Also in all the economic plant spscies examined higher concentrations of the metals ( $\mathrm{Mn} \mathrm{Fe}, \mathrm{Cu} . \mathrm{Zn}, \mathrm{C} . \mathrm{d}, \mathrm{Cr}$, $\mathrm{Pb}, \mathrm{Ni}$ ) were recorded from those growing within the immediate vicinity of the quarry $(0 \mathrm{knl})$ thari those growing at $0.75 \mathrm{~km}$ or at $2 \mathrm{~km}$ away from the quarry. The entrancad concentrations of these trace metals is an indication that they were more avalatie for absorption by the plants at the quarry site than other areas farther away. Among the 6 piant species sampled. Manihot esculenta and Colociasia esculanta which are tuber and root crops respectively had higher concentration of $\mathrm{Pb}, \mathrm{Mn}$ and $\mathrm{Fe}$ in their leaves (Table 3). The mean concentration of $\mathrm{Pb} . \mathrm{Mn}$ and $\mathrm{Fe}$ in Colocasia esculenta and Manihot esculenta declined significantly in the farthest sampling pcsition from the quarry $(2 \mathrm{~km}$ ) (Table 4). The decline in concentrations of these metals as the distance from the quarry increases further shows that the quarrying operatizn is strongly ass'sciated with the build up of the irace metals in the plants. In most instances the concentration level of these metals in soil is less than that in plants. Many authors have indicated that the concentration of trace metals contained in plants may be higher than that of the soil on which they are growing due to bicmagnifications and bioaccumulation (Ponyat and McDonnel, 1991). This also suggests the existence of other possible factors such as type of soil and plant species that affect nutrient absorption process which ultimately contribute in determining the level of heavy metals in plants (Egunjobi and Nwoko, 2002). The concentration of some of these metals reported in this study was well over the recommended level of $0.05 \mathrm{mg} / \mathrm{kg}$ for vegetaile species (FEPA, 1991).

This rarses a lot of environmental concern because both man and livestock depend on these plant species for focd consequently they are inadvertently exposed to graduat accumulation of these heavy metals. In a related study. high Fis level was found in the blood sample of cattle reaied near' $a$ lead smelter plant (Neuman and Dollhopt, 1y92)

Thi concentrations of $\mathrm{Zn}, \mathrm{Cu}$ and $\mathrm{Ni}$ were found to be higier amorig the fruit crops (Carica pespaya and Magifera indica) than in other species sampled. The concentration of $\mathrm{Zn} . \mathrm{Cu}$ and $\mathrm{Ni}$ in Magifera indica and Carica papaya were 21.36 and 23.25 for $\mathrm{Zn}, 21.50$ and 18.95 for $\mathrm{Cu} ; 26.08$ and 24.95 (mg/kg) for $\mathrm{Ni}^{\text {" }}$ respectively. The percentage concentrations of $\mathrm{Zn}, \mathrm{Cu}$ and $\mathrm{N} i$ in leaves of Magifera indica 
collected from the farthest sampling position from the quarry were lower by $81 \%, 63.04 \%$ and $51.93 \%$ respectively than t'lat of plant leaves collected from immediate vicinity the quarry site. Also the leaves of Carica papaya occurning in the farthest sampling point had concentrations of $\mathrm{Zn}, \mathrm{Cu}$ and $\mathrm{Ni}$ reduced by $75 \%, 48.92 \%$ and $59.77 \%$ when compared with stands of $C$. papaya occurring in the immediate vicinity of the quarry. The concentrations of these metals tend to decline as the distance from the quarry increases. Table 4 shows the concentrations of $\mathrm{Cd}$ and $\mathrm{Cr}$ in Centrosema pubescens and Aspilia africana as being higher than those other plant species evaluated in the immediate vicinity of the quarry $(0 \mathrm{~km})$. The values of $\mathrm{Cd}$ and $\mathrm{Cr}$ in these 2 plants decreased away from the immediate vicinity quarrying site. Aspilia africana consistently had higher concentrations of both $\mathrm{Cd}$ and $\mathrm{Cr}$ than other plant species in all the sampling position even at $2 \mathrm{~km}$ distance from the immediate vicinity of the quarry. This shows that the capacity to absorb $\mathrm{Cd}$ and $\mathrm{Cr}$ is enhanced in this fodder species than the other type of plants. The significant concentration of these neavy metais in plant leaves at sampling position within the quarrying site indicates that the waste generated from the quarry is a major contributor of these metals to the vegetation and soil systems. The values obtained in this study were above the recommended range of $0.1-24 \mathrm{mg} / \mathrm{kg}$ regarded as the maximum acceptable level for Co in plant (Bowen. 1979). Cd levels greater than $5 \mathrm{mg} / \mathrm{kg}$ had been reported as toxic to plants (Alloway 1995).

From the investigation no single plant species had highest concentrations in the entire heavy metals analyzed. This is attributable to their varying physiological differences and relative selectivity in rate of uptake of minerals. Also the metals are not equally available for absorption by plants, a factor dependent on the ionic form which the metals were occurring in the soil (Nwoboshi, 2000). Occurrence of heavy metals above the acceptable tolerance levels are particularly hazardous because of its uptake by plants, tendency to accumulate in food chain and its persistence once in the environment (Dudka and Adriano, 1997).

Although the present levels of some of these trace metals, for instance, iron and manganese pose no toxicity problem there is need to regulate and control the waste produced from quarrying activities in order to prevent the introduction of further excessive heavy metals into the existing food chain considering that the area is an agricultural zone

Table 3. The mean concentrations $(\mathrm{mg} / \mathrm{kg}$ ) of some heavy metals in the soils at different sampling distances from the quarry

\begin{tabular}{|l|l|l|l|l|l|l|l|l|}
\hline $\begin{array}{l}\text { Sampling } \\
\text { positions }\end{array}$ & $\mathrm{Mn}$ & $\mathrm{Fe}$ & $\mathrm{Cu}$ & $\mathrm{Zn}$ & $\mathrm{Cd}$ & $\mathrm{Cr}$ & $\mathrm{Ni}$ & $\mathrm{Pb}$ \\
\hline $0 \mathrm{~km}$ & $28.75 \pm 3.85$ & $950.25 \pm 2.85$ & $92.24 \pm 7.26$ & $21.13 \pm 4.26$ & $8.25 \pm 1.24$ & $1.45 \pm 0.82$ & 3.25 \\
$0.75 \mathrm{~km}$ & $17.92 \pm 4.28$ & $520.35 \pm 3.75$ & $94.26 \pm 3.27$ & $16.25 \pm 1.29$ & $3.28 \pm 0.29$ & $1.05 \pm 2.74$ & $2.98 \pm 0.45$ & $14.27 \pm 2.08$ \\
$2 \mathrm{~km}$ (control) & $12.05 \pm 2.28$ & $346.08 \pm 2.96$ & $82.28 \pm 5.28$ & $12.48 \pm 9.68$ & $1.49+1.28$ & $1.08 \pm 0.05$ & $2.45 \pm 0.55$ & $5.36 \pm 0.82$ \\
\hline
\end{tabular}

4: $\quad$ Standard error of mean 

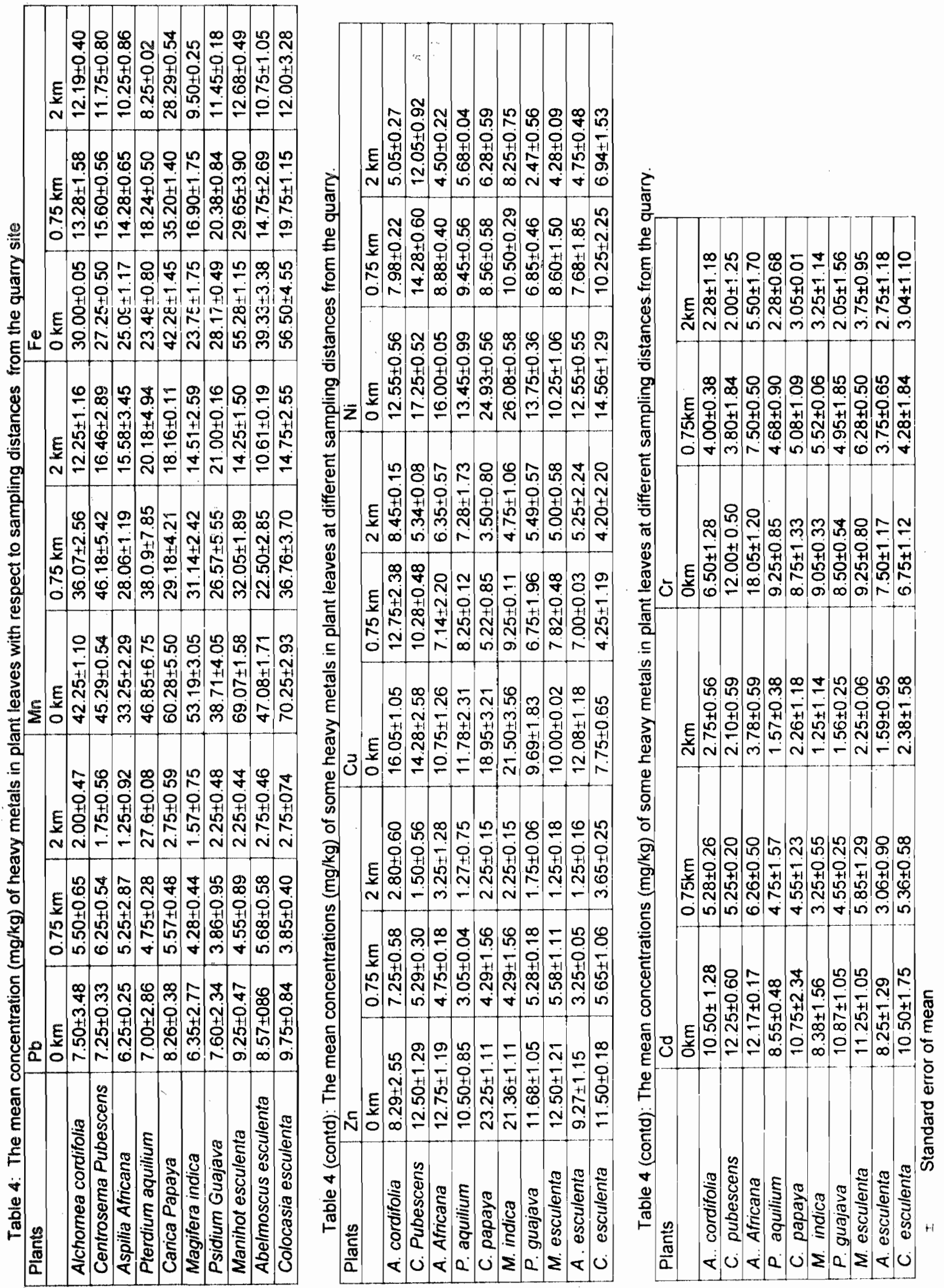


\section{REFERENCES}

Adepoju, S. O.. 2002. Effects of alluvial Gold Extraction on Water Soil Acidity and Organic matter at Igun Nigeria J. Engineering (1) 30-33.

Alloway, B. J., 1990. Heavy metals in soils. Blaki (Pub!) Glasgow. U. K P324

Alloway, B. J., 1995. Heavy metals in soils $2^{\text {nd }}(e d)$. Black and San (Publ.) Glasgow Pp. 278.

Bowen, H. J., 1979. Environmental Chemistry of the Elernents Academic Press London Pp91-120.

Brown R., 1979. Lead in the home garden ana urban soil environment Regents of the University of Minnesota http:I WMW. Extension. Umu. Edu/distribution/horticulture/DG 2543. html.

Dudka, so and Adriano, C., 1997. Environmental impact of meial, mining and processing. A Review J. Environ Quality: 26:590-602

Ellen, O. V., 2000. U. S. Environmental protection Agency, Office of Compliance, profile of metal mining industry Washington, O. C. U. S. EPA Report No. EPA 31012-95-008.

Egunjobi, P. and Nwoko, J., 2002. Differential accumulation of lead on selected edible vegetables associated with road side gardening in Nigeria. Trop. J. Applied Sc. 2 (1): $29-35$

FEPA., 1991. National Guidelines and Standards for industrial Effluents, Gaseous Emission and Hazardous Waste Management in Nigeria Pp 59-66.

Kakulu, S. E. 2003 Trace metals in Soils and Vegetation from Some Tin Mining Area in Nigeria. Global J. of Pure an Applied Sc. 9 (3):331-337.
Mattigod, S. V. Page, A. and Lyle, E., 1983. Assessment of Metai Pollution in Soils. in: I. Thronton (ed). Applied Environmental Geochemistry. Academic press New York P. 488.

Neumani, I. and Dolthopt, 1992. Lead levels in blood from cattle residing near a Pb smelter. J. Environ. Quality 21 (2) 181-185.

Nwoboshi, L. C., 2000. The nutrient factor in sustainabie forestry. Ibadan University Press. Pp303

Nriagu, J. O., 1990. Global metal Pollution, Poisoning the Biosphere. Environment. 327-23.

NPC., 1991, Population Census of Cross River State. In census 1991; National Summary. National Popuiation Commission (NPC), Abuja, Nigeria.

Okere, U. J., Ugwu, T. O., Ufot, U. $\odot$. and Akamigbo, $F$. 2001. Management of Wet Land Soils for Sustainable Agriculture and Environment. Proceedings of the 27ith Annual Conference of the Soil Science Society of Nigeria. PP $291-294$

Ponyat, R. V. and MCDonnel, M. Y., 1991. Heavy metal accumulation of forest Soil along an urban, rural gradient, in south Eastern New York. Air' soil pollution and U.S. water 23 (56): 797-807.

Steel, R. G. and Torrie, J. H., 1980. Principles and Procedures of Statistics. A Biometrical Approach and Edition Mcgraw-hill Book Company N.G. Pp 63.

Vousta, D.: Grimanies, A and Samara, C., 1996. Trace elements in vegetables grown in an industrial Area in relation to soil and air particulate matter. J. Environ. Pollut. 94(3) 325-335.

Wills, M. C., 1995. Studies of copper and zinc forms in some polish and Egyptian soils: part II Distribution of some copper and zinc in soils profiles. Polish J. Soil. Sci. II (I) $34-41$ 